Asian Journal of Information Science and Technology ISSN: 2231-6108 Vol.11 No.1, 2021, pp.15-25

(C) The Research Publication, www.trp.org.in https://doi.org/10.51983/ajist-2021.11.1.2658

\title{
Research Contributions of Nobel Laureate Jacques Dubochet: A Study of Bibliometric Analysis
}

\author{
Prakash Kumbar $^{1}$ and Mallinath Kumbar ${ }^{2}$ \\ ${ }^{1}$ Research Scholar, ${ }^{2}$ Professor \\ ${ }^{1 \& 2}$ Department of Library and Information Science, University of Mysore, Karnataka, India \\ E-mail: prakashkumbar24@gmail.com
}

\begin{abstract}
The study is aims to provide the single author analysis evaluating the scientific contributions of Dubochet in chemistry, who is a recipient of the Nobel Prize in the field of Chemistry in 2017. He has published 97 publications with 5672 citations during his scientific career. Most of the publications have resulted in collaboration which accounts for 86 . Biochemistry is one of his most favoured domain in which he has published 48 publications; most active collaborators are Stasiak, A with22 publications, Adrian, M13, Bednar, J11, Furrer, P10 publications. Journal articles are the most common channel of communication, where he published 65 publications of 97. His research picks top speed in the year 2009, where he has published nine publications, his $H$-index accounts for 43. Finally paper concluded that Dubochet $\mathbf{J}$ contribution in the field of "Cryoelectron microscopy" high-resolution structure determination of biomolecules in solution. The study is compiled to prove the Dubochet $J$ as a source of information for upcoming researchers, fellow scientists in chemistry and Library and Information centres.

Keywords: Bibliometrics, Growth Trend of Publications, Citations Analysis, Co-Authorship, h-index, Impact Factor, VOS Viewer
\end{abstract}

\section{INTRODUCTION}

Evaluation is a tool that helps determine the quantity, quality, and value of something or someone; likewise, bibliometric studies help determine individuals, institutions, or a nation's research productivity. Scientific publications seem to have provided the best available basis for measuring individual scientists' output as their good correlation between the eminence of scientist and their sustained research publications (Price 1986). (Kalyane \& Kalyane, 1993) the term 'Scientometric Portrait' came into the picture in the paper 'Scientometric Portrait of Vinodini Reddy' authored by Kalyane and Kalyane.(Qayyum \& Naseer, 2013) have explained the scientometric portrait, which includes the mathematical and statistical techniques to analyse a pattern of the publication's, preferences, collaboration and chronological distribution of publications. From the scientometric analysis, it is possible to develop a model on the performance of a role model scientist of a country who has a immediate bearing on the identity of promising scientist and human resource improvement in growing countries (Kademani, Kalyane \& Kumar 2001). Individual scientists, including the Nobel laureates, have grown to be focal point of scientometric research for quite some time. Ever-growing stress has been laid on scientometrics to publish data on individual scientist rather than gross statistical "macro" data (Schubert \&Glanzel 1992). Scientometric studies are highly valued by historians of science, biographers of a scientist, science policymakers, and administrators of scientific establishments, R\&D managers, document lists, information scientists and journalists (Hazarika et al., 2010)

\section{BRIEF BIO-SKETCH OF JACQUES DUBOCHET}

Jacques Dubochet, a retired Swiss biophysicist, was born in Aigle, Switzerland, on 8 June 1942. In his family, he has five members, namely his father, mother, brother, and sister. His father was a trained civil engineer who worked for the German army. When he went to the big city of $\mathrm{Si}$ on in 1948, he made his way through a more conventional education system with difficulties. His school results were not promising, his parents noted his and his brother's mistakes, and they called the college manager's attention to this matter. This led to him being promoted to the next class with more appealing grades. His parents sent him to Kantonschule Trogen, a Swiss-German boarding school for better education. In 2017, the Nobel Prize in Chemical Sciences demonstrated that becoming a bad boy in school can also earn an outstanding award through hard work. Dubochet's examination was essential to the development of cryo-electron microscopy, which permits analysts to assemble snaps of organic materials, that all the more almost took after the normal condition of the material. He explores different avenues to improve the methodologies for primary imaging of natural materials by his most used cryoelectron microscopy method. He offered progression to a strategy known as cryo EM of the glassy segment, which specialist could execute to verify the cells and tissues for the perception of new primary detail; he likewise concentrated on DNA and chromatin on its underlying viewpoints (Rogers, 2019).

\section{LITERATURE STUDY}

Considerable numbers of studies have been presented on individual scientist in various subject domains, in this section reviewed scientometric studies on Nobel Laureates in Science disciplines, they are: (Gupta, 1983) has conducted citation analysis study on S. Chandrashekar Nobel Laureate in physics, opines that high correlation in quantity, quality of works, citedness and receiving honours 
and awards, and opines that he has set up a very high standard for his followers to surpass it. (Lancaster et al., 1992) have carried out the bibliometric analysis of the citations obtained by Ranganathan. The study includes evaluating bibliometrics's parameter, and the author shows that Ranganathan has an outstanding performer in the field.(Kademani et al., 1994) have thrown light on Noble Laureate's scientific career in Physics C V Raman, studied the activeness in his research productions which, in which they have proved that C V Raman as a role model. (Kalyane \& Sen, 1996) have evaluated 422 research outcomes of Pierre-Gilles de Gennes Nobel Prize winner in Physics with scientometric concepts of a productive career; in this study, they applied Bradford's law of scattering to know the ratio of article scattered in journals.

(Kalyane \& Kademani, 1997) conducted a scientometric survey of Nobel Laureate in Physiology Barabara McClintock, in which they have focused on the productive life of McClintock, more than $90 \%$ of papers follows solo authorship pattern. (Kademani et al., 2001) have tested with elements of scientometrics of 246 publications by Nobel Laureate in Chemistry Ahmed Hassan Zewail. Authors opine that awards and honours capable of grabbing the attention of fellow researchers in the field. (Rushton, 2001) has described Hans Eysenck's productivity in which evaluated for the influence of publications accounts for 748 citations. (Kademani et al., 2002) demonstrated a detailed scientometric analysis of 192 publications of Harold Kroto, Winner of Nobel Prize in Chemistry. They have provided details about the publication growth, dominant collaborator, core journals to publish his papers, general keywords used in the paper. (Koganuramath et al., 2004)studied the 115 research output of Nobel Laureate in Physics Ketterle are tested scientometrically to prove that he is role model for fellow researchers in Physics, suggested that 'Scientometric portrait' is appropriated phrase for studies on scientists and 'Informetric portrait' for the researchers in other disciplines. (Kademani et al., 2006) have presented the scientometric study on Noble Laureate in Chemistry Dorothy Crowfoot Hodgkin in the publications examined with biobibliometric concepts. (Sangam et al., 2006) have explored the research pattern of G. N. Ramachandran, in which they elaborated on productive career output scattered in various field and has proven that he is the role model for the younger scientist in the field of chemistry. (Sangam et al., 2006) have brought scientometric portrait study on Prof. Peter John Wyllie which is an exploratory study includes the citations, authorship details, source titles used for communication, authorship credits etc. (Akakandelwa, 2008) has carried out to portrait the life sketch of Processor SeterSiziya concentrating on emphasis on his research contribution in medicine, findings of the study have indicated that professor Siziya has a brilliant and outstanding academic and research career. Varaprasad et al., 2010) have illustrated the quantitative increase and improvement of chemical studies by J. S. Yadav for the period from 1986-2009. The study indicates Yadav's publication productivity and the nature of the research activities. He is eminently certified to be taken as a role model for younger generations to emulate. (Kumbar \& Harinarayan 2012) have conducted a study on H S Yathirajan, a professor in the Dept. of Chemistry at the University of Mysore. Authors opine that Yathirajan has well in collective scientific research work. (GonzálezAlcaide, 2014) has tried to identify the bibliometric references to the papers published by Santiago Garisolia. Authors opine that young scientists may follow the pattern set by Santiago to achieve scientific excellence. (Balutagi et al., 2020) have measured the research contributions of Prof. Anurag Kumar, and authors opine that scientometric portrait studies will be the source of inspiration and productivity for young professionals in the field. (Kumbar and Kumbar, 2021) have illustrated the research contributions made by Nobel Laureate Arnold FH, in they we can find the data analysed for basic scientometric concepts, and proved that Arnold FD is trend setter in the field of Chemical Sciences.

\section{OBJECTIVES OF THE STUDY}

1. The bibliometric study is to assess the publications produced by Nobel Laureate Dubochet depend on publications indexed in the WoS database.

2. Chronological growth trend in publications; and most prolific research collaborators.

3. To get the information on solo and single-authored publications.

4. Most relevant source titles with impact factor.

5. To know countries cited Dubochet's work and most frequent words used in the publications and get insights on citations pattern of Dubochet J.

\section{METHODS AND TOOLS}

The publication data for the bibliometric study on Dubochet was sourced from the Web of Science (WoS) citations database (https://apps.webofknowledge.com). Data for the analysis were obtained using the search string as 'author name' in the search box. As a result, 97 documents were retrieved as the author Dubochet and all of the retrieved documents were used as the base data for further analysis. VOS viewer software 2021 was used to develop Cooccurrences of author keywords, terms of papers published by Dubochet $\mathrm{J}$ and Co-authorship networks of authors and countries distributed within a similar period.

\section{RESULTS OF THE STUDY}

\section{A. Chronological Distribution of Publications}

As observed from the WoS database, the total research out of Dubochet is 97 presented in Table-I, which is obtained 5672 citations during his scientific career. It is observed in the study that his publication productivity trend has constant growth with an average publication per year of 4 , and it reaches at peak level in the year 2009in which he has produced nine research publications, followed by 8 in 2005.He has 15 collaborators for one paper which was considered his mega collaborated publication. The growth trend of publications may inspire upcoming generations to contribute to the field. 
TABLE I CHRONOLOGICAL DISTRIBUTION OF PUBLICATIONS

\begin{tabular}{|l|c|c|c|c|c|c|c|c|c|c|c|c|c|c|}
\hline \multicolumn{1}{|c|}{ Year } & $\mathbf{1}$ & $\mathbf{2}$ & $\mathbf{3}$ & $\mathbf{4}$ & $\mathbf{5}$ & $\mathbf{6}$ & $\mathbf{7}$ & $\mathbf{8}$ & $\mathbf{9}$ & $\mathbf{>}=\mathbf{1 0}$ & $\mathbf{M T}$ & $\mathbf{T P}$ & $\mathbf{C u m}$. & TC \\
\hline $1989-1993$ & & & 4 & 1 & 2 & 3 & & & & 1 & 11 & 11 & 11 & 443 \\
\hline $1994-1998$ & 1 & & 2 & 8 & 5 & 6 & 2 & 1 & & 1 & 25 & 26 & 37 & 1607 \\
\hline $1999-2003$ & 2 & 1 & 3 & 4 & 8 & & & 2 & & & 18 & 20 & 57 & 1002 \\
\hline $2004-2008$ & 3 & 4 & 6 & 1 & 2 & 4 & 2 & & 2 & 5 & 26 & 29 & 86 & 2400 \\
\hline $2009-2016$ & 4 & & & & & 1 & 3 & & & & 4 & 8 & 94 & 209 \\
\hline $2018 *$ & 1 & 1 & 1 & & & & & & & & 2 & 3 & 97 & 11 \\
\hline Total & 11 & 6 & 16 & 14 & 17 & 13 & 7 & 3 & 2 & 7 & 86 & 97 & & 5672 \\
\hline
\end{tabular}

\section{B. Channels of Communication}

Journals are the primary source of information, and users are regularly searching and customizing to get the updated information produced in their areas (Soni et al., 2020). The medium of research communication is one of the essential steps to convey information in a better way. Of total publications of Dubochet, 65 have appeared in journals; eight are in the form of editorial material, seven as reviews etc. are provided in Table II while comparing to other medium journal articles are the most common and preferable medium of research communication, that's why Dubochet may select his medium of research communication as journal articles which are presented, we can find that he has published in all the forms of channels to communicate his research in the field of chemistry. Dubochet has considered journals as the main channels of communications for his publications.

TABLE II CHANNELS OF COMMUNICATION

\begin{tabular}{|l|c|c|c|c|}
\hline \multicolumn{1}{|c|}{ Document Type } & TP & \% & TC & \% \\
\hline Article & 65 & 67.01 & 4637 & 81.75 \\
\hline Editorial Material & 8 & 8.25 & 68 & 1.20 \\
\hline Review & 7 & 7.22 & 571 & 10.07 \\
\hline Article; Proceedings Paper & 5 & 5.15 & 88 & 1.55 \\
\hline Letter & 4 & 4.12 & 186 & 3.28 \\
\hline Correction & 2 & 2.06 & 1 & 0.02 \\
\hline Meeting Abstract & 2 & 2.06 & 0 & 0 \\
\hline Review; Book Chapter & 2 & 2.06 & 118 & 2.08 \\
\hline Biographical-Item & 1 & 1.03 & 1 & 0.02 \\
\hline Note & 1 & 1.03 & 2 & 0.04 \\
\hline Total & 97 & 100 & 5672 & 100 \\
\hline \multicolumn{5}{|c|}{ TP= Total Publications, TC= Total Citations } \\
\hline
\end{tabular}

\section{Domains of Publications}

Dubochet has published his 97 publications in seven subdomains of chemistry which are provided in Table-III and Figure 1. Of which Biochemistry is one of his fevered domain in which he has recorded 48 papers with more than 2661 citations, 24 papers in Molecular Chemistry with 1651 citations, 10 in Organic Chemistry with 524 citations, 7 in Multidisciplinary 274 citations, 4 in Chemical Biochemistry with 276 citations, 2 in Miscellaneous and Physical Chemistry with 249 and 37 citations each.

These scientific domains of publications may be useful for the classification of the subject and building ontology.

TABLE III DOMAINS OF PUBLICATION

\begin{tabular}{|l|c|c|c|c|}
\hline \multicolumn{1}{|c|}{ Domains } & TP & $\mathbf{~ \% ~}$ & TC & \% \\
\hline Biochemistry & 48 & 49.48 & 2661 & 46.91 \\
\hline Molecular Chemistry & 24 & 24.74 & 1651 & 29.11 \\
\hline Organic Chemistry & 10 & 10.31 & 524 & 9.24 \\
\hline Multidisciplinary & 7 & 7.22 & 274 & 4.83 \\
\hline Chemical Biochemistry & 4 & 4.12 & 276 & 4.87 \\
\hline Miscellaneous & 2 & 2.06 & 249 & 4.39 \\
\hline Physical Chemistry & 2 & 2.06 & 37 & 0.65 \\
\hline Total & 97 & 100 & 5672 & 100 \\
\hline \multicolumn{5}{|c|}{ TP= Total Publications, TC= Total Citations } \\
\hline
\end{tabular}

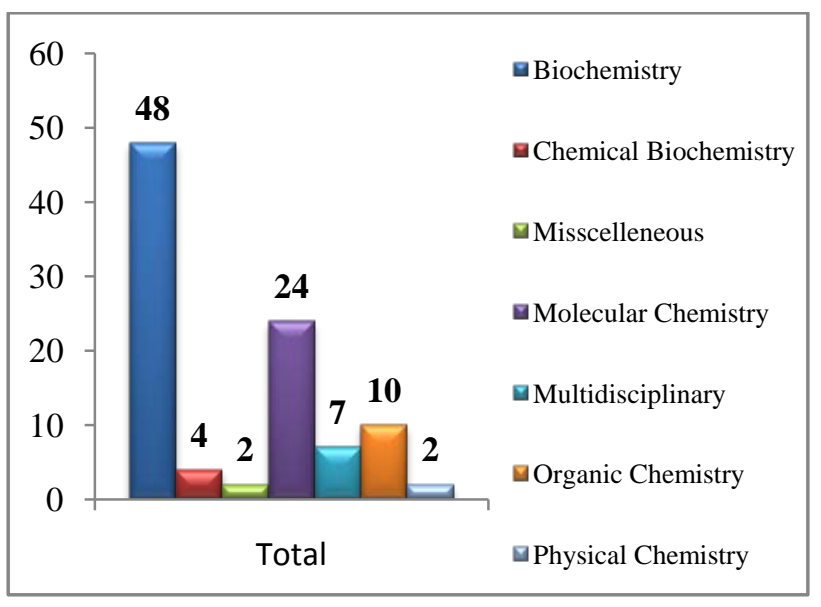

Fig.1 Domains of Publication 


\section{Authorship Pattern}

The authorship pattern reflects the type of collaboration between the authors, which was shown in Table-IV. Dubochet has recorded a total of 473 authorships in different domains for his 97 publications.

\begin{tabular}{l} 
TABLE IV AUTHORSHIP PATTERN IN VARIOUS DOMAINS \\
\begin{tabular}{|c|c|c|c|c|c|c|c|c|c|}
\hline $\begin{array}{c}\text { No. of } \\
\text { Authors }\end{array}$ & A & B & C & D & E & F & G & TP & NA \\
\hline 1 & 9 & 1 & & & & & 1 & 11 & 11 \\
\hline 2 & 4 & & & 1 & & 1 & & 6 & 12 \\
\hline 3 & 9 & & 1 & 3 & 1 & 2 & & 16 & 48 \\
\hline 4 & 5 & & & 5 & 2 & 1 & 1 & 14 & 56 \\
\hline 5 & 7 & 1 & 1 & 4 & 2 & 2 & & 17 & 85 \\
\hline 6 & 5 & & & 6 & 1 & 1 & & 13 & 78 \\
\hline 7 & 3 & 1 & & 2 & & 1 & & 7 & 49 \\
\hline 8 & & & & & 1 & 2 & & 3 & 24 \\
\hline 9 & 2 & & & & & & & 2 & 18 \\
\hline 10 & 1 & 1 & & 2 & & & & 4 & 40 \\
\hline 12 & 1 & & & 1 & & & & 2 & 24 \\
\hline 13 & 1 & & & & & & & 1 & 13 \\
\hline 15 & 1 & & & & & & 1 & 15 \\
\hline
\end{tabular} \\
\hline $\begin{array}{l}\text { Total } \\
\text { A=Biochemistry, B=Chemical Biochemistry, C= }\end{array}$ \\
\hline $\begin{array}{l}\text { Miscellaneous, D= Molecular Chemistry, E= Multidisciplinary, } \\
\text { F= Organic Chemistry, G= Physical Chemistry }\end{array}$ \\
\hline
\end{tabular}

The above table data indicates that he can publish his works in collaboration instead of publishing in single-authored publications. Of total authorship,15 and 13 authored publications are considered mega collaborated publications and found five authored publications that account for 17 of 97 publications by Dubochet, $\mathrm{A}=$ Biochemistry domain emerged tops in all types of authorships which resulted in the 48 publications. It is observed that the mega collaborated works recorded in the single-digit of 1 . It is observed that there is an increasing trend of collaborative research in the field of chemistry.

\section{E. Dominant Source Titles in Publications of Dubochet $J$}

Research publications of Dubochet J comprising 97 articles were published across 42 journals during 1989-2019, illustrated in Table V. Journals have been arranged in decreasing order of the number of publications with citations, among these journals which are performed outstand are; Journal of Structural Biology with 11 papers and 576 citations was, followed by Journal of Microscopy9 papers with 336 citations, Journal of Molecular Biology 7 papers with 594 citations, Journal of Bacteriology 6 papers with 589 citations Biophysical Journal with 134 citations; The Nature journal is having high impact factor of 42.77 in which he has been published five papers which obtain 471 citations and his h-index accounts for 43.

These 42 journals were considered the core journals in the field of chemistry.

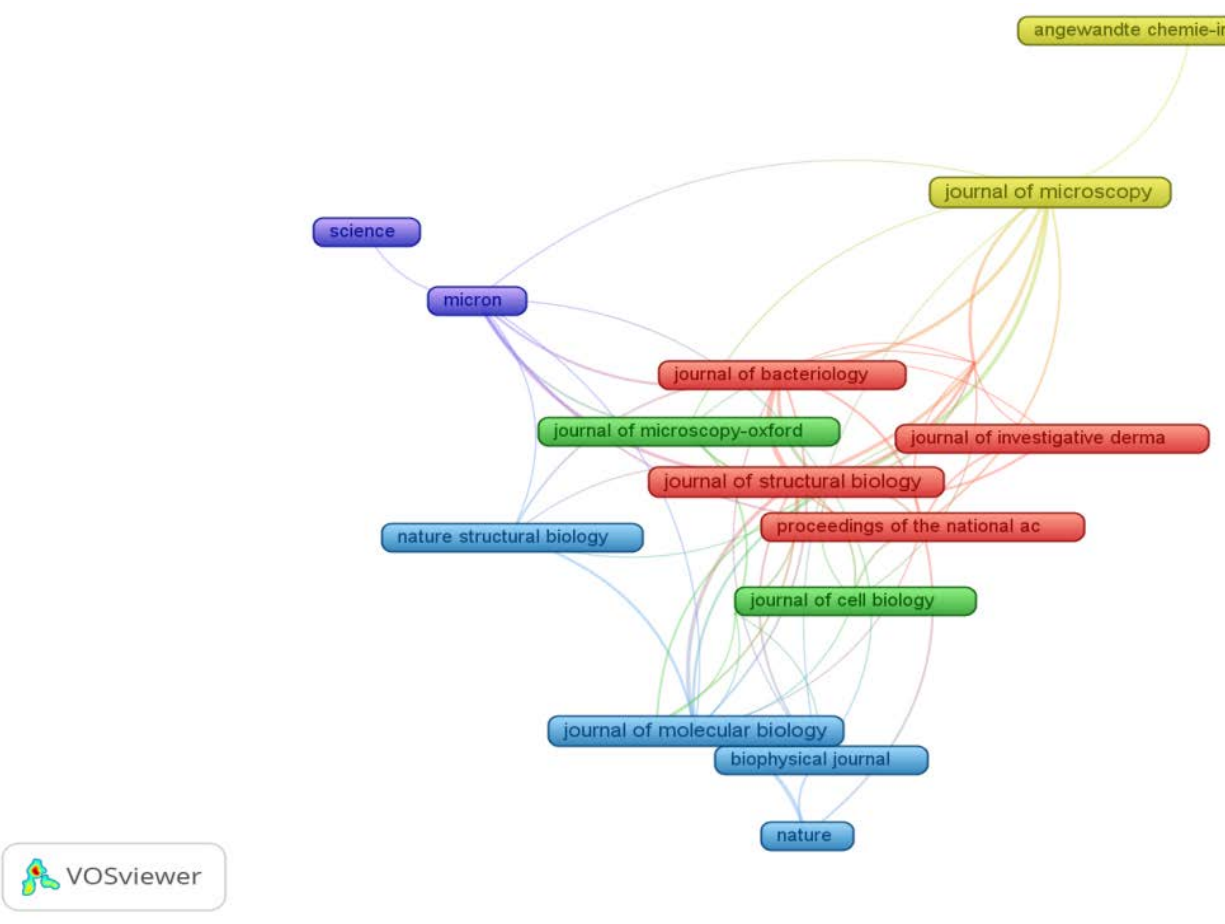

Fig. 2 Dominant Source Titles of Publications by Dubochet J 


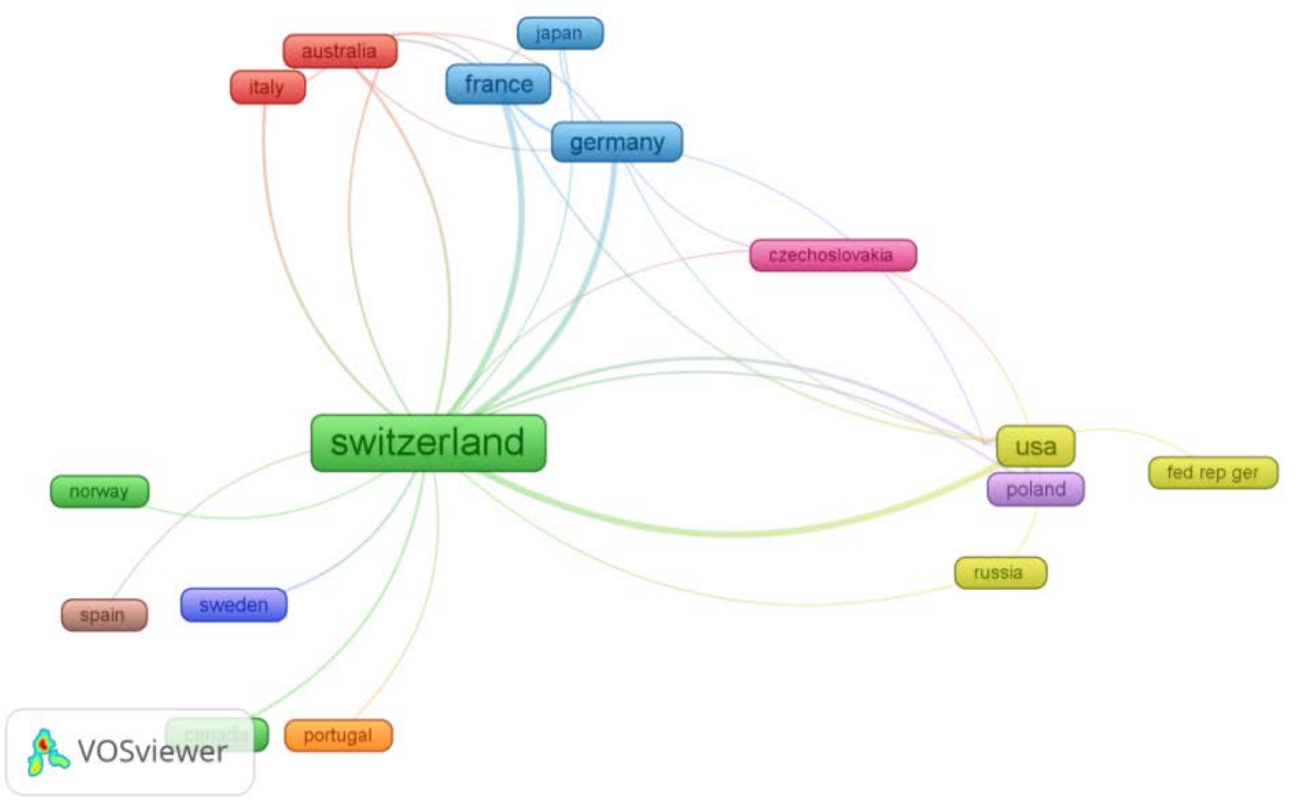

Fig. 3 Prolific Countries

TABLE V DOMINANT SOURCE TITLES PREFERRED FOR PUBLICATIONS BY DUBOCHET J

\begin{tabular}{|c|c|c|c|c|}
\hline Sl. No. & Name of Source Title & $\mathbf{T P}$ & TC & IF \\
\hline 1 & Journal of Structural Biology & 11 & 576 & 3.071 \\
\hline 2 & Journal of Microscopy & 9 & 336 & 1.575 \\
\hline 3 & Journal of Molecular Biology & 7 & 594 & 4.760 \\
\hline 4 & Journal of Bacteriology & 6 & 589 & 3.004 \\
\hline 5 & Biophysical Journal & 5 & 134 & 3.854 \\
\hline 6 & Nature & 5 & 471 & 42.778 \\
\hline 7 & Embo Journal & 3 & 479 & 9.889 \\
\hline 8 & Embo Reports & 3 & 13 & 7.497 \\
\hline 9 & Journal of Microscopy-Oxford & 3 & 57 & 1.575 \\
\hline 10 & Micron & 3 & 197 & 1.726 \\
\hline 11 & $\begin{array}{l}\text { Proceedings of The National Academy of Sciences of The United States of } \\
\text { America }\end{array}$ & 3 & 427 & 9.35 \\
\hline 12 & Angewandte Chemie-International Edition & 2 & 182 & 12.959 \\
\hline 13 & Cellular Electron Microscopy & 2 & 118 & - \\
\hline 14 & Journal of Cell Biology & 2 & 189 & 8.811 \\
\hline 15 & Journal of Electron Microscopy Technique & 2 & 71 & 2.117 \\
\hline 16 & Journal of Investigative Dermatology & 2 & 104 & 7.143 \\
\hline 17 & Nature Structural Biology & 2 & 58 & 11.980 \\
\hline 18 & Nucleic Acids Research & 2 & 65 & 11.501 \\
\hline 19 & Science & 2 & 428 & 41.845 \\
\hline \multicolumn{2}{|c|}{ Total of $1-19$} & 74 & 5088 & \\
\hline \multicolumn{2}{|c|}{ Total of remaining 23 source titles } & 23 & 584 & \\
\hline \multicolumn{2}{|c|}{ Grand total } & 97 & 5672 & \\
\hline \multicolumn{5}{|c|}{$\mathrm{TP}=$ Total Publications, $\mathrm{TC}=$ Total Citations, $\mathrm{IF}=$ Impact Factor } \\
\hline
\end{tabular}




\section{F. Citation Trend Analysis}

Several citations may represent the quality of work done by an individual scientist. Data presented in Table VI replicates that the range of references per articles. During the study period, Dubochet has been responsible for to publish 97 papers, of which six articles remained uncited till now. Of total publications, 22 publications obtain citations ranged between 1-50, which was then considered the largest group in ranges; was followed by 19 publications receives citations ranged between $>=100$. One publication in a range of 76-85 was considered a low group ranging, which clearly indicates that the quality publications may attract more citations.

\begin{tabular}{|c|c|c|c|c|c|c|c|c|c|}
\hline Year & $\mathbf{0}$ & $\mathbf{1 - 1 5}$ & $\mathbf{1 6 - 3 0}$ & $\mathbf{3 1 - 4 5}$ & $\mathbf{4 6 - 6 0}$ & $\mathbf{6 1 - 7 5}$ & $\mathbf{7 6 - 8 5}$ & $>\mathbf{1 0 0}$ & $\mathbf{T P}$ \\
\hline 1989 & & 1 & 1 & & & & & & 2 \\
\hline 1990 & & & & & 1 & & & 1 & 2 \\
\hline 1991 & & 1 & 2 & 1 & & & & & 4 \\
\hline 1992 & & & 1 & & & 1 & & & 2 \\
\hline 1993 & & & & & 1 & & & & 1 \\
\hline 1994 & & & 2 & & 1 & & & 1 & 4 \\
\hline 1995 & & 2 & & 1 & 1 & & & 2 & 6 \\
\hline 1996 & 1 & 2 & 1 & 1 & & & & 2 & 7 \\
\hline 1997 & & & 1 & & & & 1 & & 2 \\
\hline 1998 & 1 & 1 & & 3 & & & & 2 & 7 \\
\hline 1999 & & 2 & 1 & & & & & & 3 \\
\hline 2000 & & & & & 1 & & & 1 & 2 \\
\hline 2001 & 1 & 1 & 1 & 2 & 1 & 1 & & & 7 \\
\hline 2002 & & & & 3 & 1 & & & & 4 \\
\hline 2003 & & 1 & & 1 & 1 & & & 2 & 5 \\
\hline 2004 & & & & & & & & 3 & 3 \\
\hline 2005 & & 2 & & 2 & 1 & 1 & & 2 & 8 \\
\hline 2006 & 1 & 3 & & 1 & 2 & 1 & & 1 & 9 \\
\hline 2007 & & & & & 2 & 1 & & & 3 \\
\hline 2008 & & 2 & 1 & & & & & 2 & 5 \\
\hline 2009 & & 1 & & 3 & & & & & 4 \\
\hline 2010 & & & & 1 & & & & & 1 \\
\hline 2011 & 1 & & & & & & & & 1 \\
\hline 2012 & & & & & 1 & & & & 1 \\
\hline 2013 & & & & & & & & & 0 \\
\hline 2014 & & & & & & & & & 0 \\
\hline 2015 & & & & & & & & & 0 \\
\hline 2016 & & 1 & & & & & & & 1 \\
\hline 2017 & & & & & & & & & 0 \\
\hline 2018 & 1 & 2 & & & & & & & 3 \\
\hline 2019 & & & & & & & & & \\
\hline Total & 6 & 22 & 11 & 19 & 14 & 5 & 1 & 19 & 97 \\
\hline & & & & & & & & \\
\hline
\end{tabular}

\section{G. Highly Cited Papers of Dubochet J}

In Table VII, information on the top ten highly cited publications of Dubochet has been provided with their citations received. This table compared the citations in two databases, i.e. Google Scholar Citations (GSC) and Web of Science (WoS); the comparison of citations in both databases is quite interesting; the total citations of top 10 
highly cited publications is 3530 citations in GSC and 2296 in WoS citations. The top article receives a sum of 653 citations in GSC, while in WoS C, it is 427; it was published in Science, having an impact factor of 41.845. He has published a journal article in 'Nature' with a high impact factor of 42.778 in 1996.

Citations analysis in one the vital tool to evaluate the impact of publications produced by an individual, the single citation is also essential for the author; it may not give a comprehensive insight on citations if rely on the single database; comparison may provide a clear picture in citations analysis and these articles are considered as top 10 highly cited publications of Dubochet J. This inspires fellow and upcoming scientist in the field to work in collaboration and to get rewarded.

TABLE VII HIGHLY CITED PAPERS OF DUBOCHET J

\begin{tabular}{|c|c|c|c|c|c|}
\hline Sl. No. & Paper & PY & GSC & WoSC & IFST \\
\hline 1 & $\begin{array}{l}\text { Matsuo, H., Chevallier, J., Mayran, N., Blanc, I. L., Ferguson, C., Faure, } \\
\text { J., Blanc, N. S., Matile, S., Dubochet, J., Sadoul, R., Parton, R. G., } \\
\text { Vilbois, F., \& Gruenberg, J. (2004). And Endosome Organization. 303, } 4 .\end{array}$ & 2004 & 653 & 427 & 41.845 \\
\hline 2 & $\begin{array}{l}\text { Al-Amoudi, A., Chang, J.-J., Leforestier, A., McDowall, A., Salamin, L. } \\
\text { M., Norlén, L. P., Richter, K., Blanc, N. S., Studer, D., \& Dubochet, J. } \\
\text { (2004). Cryo-electron microscopy of vitreous sections. The EMBO } \\
\text { Journal, 23(18), 3583-3588. https://doi.org/10.1038/sj.emboj.7600366 }\end{array}$ & 2004 & 425 & 285 & 9.889 \\
\hline 3 & $\begin{array}{l}\text { Zuber, B., Chami, M., Houssin, C., Dubochet, J., Griffiths, G., \& Daffé, } \\
\text { M. (2008). Direct Visualization of the Outer Membrane of Mycobacteria } \\
\text { and Corynebacteria in Their Native State. Journal of Bacteriology, } \\
\text { 190(16), 5672-5680. https://doi.org/10.1128/JB.01919-07 }\end{array}$ & 2008 & 449 & 253 & 3.004 \\
\hline 4 & $\begin{array}{l}\text { Katritch, V., Bednar, J., Michoud, D., Scharein, R. G., Dubochet, J., } \\
\text { \&Stasiak, A. (1996). Geometry and physics of knots. Nature, 384(6605), } \\
\text { 142-145. https://doi.org/10.1038/384142a0 }\end{array}$ & 1996 & 314 & 220 & 42.778 \\
\hline 5 & $\begin{array}{l}\text { Matias, V. R. F., Al-Amoudi, A., Dubochet, J., \&Beveridge, T. J. } \\
\text { (2003). Cryo-Transmission Electron Microscopy of Frozen-Hydrated } \\
\text { Sections of Escherichia coli and Pseudomonas aeruginosa. Journal of } \\
\text { Bacteriology, 185(20), 6112-6118. } \\
\text { https://doi.org/10.1128/JB.185.20.6112-6118.2003 }\end{array}$ & 2003 & 336 & 213 & 3.004 \\
\hline 6 & $\begin{array}{l}\text { Bednar, J., Furrer, P., Stasiak, A., Dubochet, J., Egelman, E. H., \& } \\
\text { Bates, A. D. (1994). The Twist, Writhe, and Overall Shape of } \\
\text { Supercoiled DNA Change During Counterion-induced Transition from a } \\
\text { Loosely to a Tightly InterwoundSuperhelix: Possible Implications for } \\
\text { DNA Structure in Vivo. Journal of Molecular Biology, 235(3), 825-847. } \\
\text { https://doi.org/10.1006/jmbi.1994.1042 }\end{array}$ & 1994 & 264 & 209 & 4.76 \\
\hline 7 & $\begin{array}{l}\text { Eltsov, M., MacLellan, K. M., Maeshima, K., Frangakis, A. S., \& } \\
\text { Dubochet, J. (2008). Analysis of cryo-electron microscopy images does } \\
\text { not support the existence of 30-nm chromatin fibers in mitotic } \\
\text { chromosomes in situ. Proceedings of the National Academy of Sciences, } \\
\text { 105(50), 19732-19737. https://doi.org/10.1073/pnas.0810057105 }\end{array}$ & 2008 & 376 & 184 & 9.412 \\
\hline 8 & $\begin{array}{l}\text { Gopalakrishnan, G., Danelon, C., Izewska, P., Prummer, M., Bolinger, P.- } \\
\text { Y., Geissbühler, I., Demurtas, D., Dubochet, J., \& Vogel, H. (2006). } \\
\text { Multifunctional Lipid/Quantum Dot Hybrid Nanocontainers for } \\
\text { Controlled Targeting of Live Cells. AngewandteChemie, 118(33), 5604- } \\
\text { 5609. https://doi.org/10.1002/ange.200600545 }\end{array}$ & 2006 & 219 & 173 & 12.659 \\
\hline 9 & $\begin{array}{l}\text { Stasiak, A., Katritch, V., Bednar, J., Michoud, D., \& Dubochet, J. } \\
\text { (1996). Electrophoretic mobility of DNA knots. Nature, 384(6605), } \\
\text { 122-122. https://doi.org/10.1038/384122a0 }\end{array}$ & 1996 & 232 & 168 & 42.778 \\
\hline 10 & $\begin{array}{l}\text { Bednar, J., Furrer, P., Katritch, V., Stasiak, A., Dubochet, J., \&Stasiak, A. } \\
\text { (1995). Determination of DNA Persistence Length by Cryo-electron } \\
\text { Microscopy. Separation of the Static and Dynamic Contributions to the } \\
\text { Apparent Persistence Length of DNA. Journal of Molecular Biology, } \\
\text { 254(4), 579-594. https://doi.org/10.1006/jmbi.1995.0640 }\end{array}$ & 1995 & 262 & 164 & 4.76 \\
\hline Total of 110 & 3530 & 2296 & & & \\
\hline & Total of remaining 87 papers & 3376 & & & \\
\hline & Grand Total & 5672 & & & \\
\hline \multicolumn{6}{|c|}{$\begin{array}{c}\text { PY= Publication Year, GSC= Google Scholar Citations, WoSC= Web of Science Citations, } \\
\text { IFST= Impact Factor of Source Title }\end{array}$} \\
\hline
\end{tabular}




\section{H. Distribution of Citations over Various Forms of Documents}

Table VIII explores the year-wise distribution of citations over various types of documents used by Dubochet. Out of the cited references, due to heavy use of journals, the citation share of Journal articles is alone 4637of total citations receives, was followed by reviews which ware accounts for 571. It is observed by various studies on scientometrics that journal articles are the most common channel of communications for their publications. Letter account for 186, which clearly shows that the media used for communication also matters in the gathering of citations, and helps young researchers select a proper document type for publication of their research output.

TABLE VIII DISTRIBUTION OF CITATIONS OVER VARIOUS FORMS OF DOCUMENTS

\begin{tabular}{|c|c|c|c|c|c|c|c|}
\hline PY & Journal Article & $\begin{array}{c}\text { Article; } \\
\text { Proceedings Paper }\end{array}$ & Editorial Material & Letter & Review & Others & TC \\
\hline 1989 & 21 & & & 1 & & & 22 \\
\hline 1990 & 181 & & & & & & 181 \\
\hline 1991 & 86 & 15 & & & & & 101 \\
\hline 1992 & 61 & & & & 26 & & 87 \\
\hline 1993 & 52 & & & & & & 52 \\
\hline 1994 & 279 & & & 16 & & & 295 \\
\hline 1995 & 345 & & 39 & & & 2 & 386 \\
\hline 1996 & 294 & & & 168 & & & 462 \\
\hline 1997 & 105 & & & & & & 105 \\
\hline 1998 & 228 & 9 & & & 122 & & 359 \\
\hline 1999 & 34 & & & 1 & & & 35 \\
\hline 2000 & 164 & & & & & & 164 \\
\hline 2001 & 151 & & & & 75 & & 226 \\
\hline 2002 & 159 & & & & & & 159 \\
\hline 2003 & 363 & 51 & 4 & & & & 418 \\
\hline 2004 & 585 & & & & 285 & & 870 \\
\hline 2005 & 463 & & & & & 2 & 465 \\
\hline 2006 & 381 & 13 & 16 & & & & 410 \\
\hline 2007 & 55 & & & & & 118 & 173 \\
\hline 2008 & 477 & & 5 & & & & 482 \\
\hline 2009 & 104 & & 4 & & & & 108 \\
\hline 2010 & 40 & & & & & & 40 \\
\hline 2012 & & & & & 54 & & 54 \\
\hline 2016 & 7 & & & & & & 7 \\
\hline 2017 & & & & & & & 0 \\
\hline 2018 & 2 & & & & 9 & & 11 \\
\hline 2019 & & & & & & & 0 \\
\hline Total & 4637 & 88 & 68 & 186 & 571 & 122 & 5672 \\
\hline
\end{tabular}

\section{Prolific Co-Authors of Dubochet J}

About 473 authors have participated in research with Dubochet, which resulted in 97 publications during 19892019 are shown in Table IX. It is noticed that about 222 authors are responsible for the publishing of 1-5 papers each. Eight authors 6-97 paper each.
The research productivity of the top 10 most prolific authors differs from 4 to 22 publications per author. It is noticed that Stasiak, A is the most prolific author who has collaborated in the highest number of publications which accounts for 22, was further followed by Adrian, M with 13 publications, Bednar, Jwith11 publications, with ten publications; Furrer, $\mathrm{P}$ considered as the 4th most prolific collaborator of Dubochet J. Al-Amoudi, A has published 
nine publications. The authorship credit for 230 authors is 473; every collaborator is being given each one authorship credit for each publication published. Dubochet $\mathrm{J}$ himself has shared more than 20 percentages $97 / 473$ of total authorship credit, shown Co-authorship network of Dubochet in figure 4. This authorship network will provide to identify notable experts in the field.

TABLE IX PROLIFIC CO-AUTHORS OF DUBOCHET J

\begin{tabular}{|c|l|c|c|c|c|}
\hline Sl.No. & Name of co-author & NA & Cum. & TC & Total Link Strength \\
\hline 1 & Dubochet, J & 97 & 97 & 5672 & 285 \\
\hline 2 & Stasiak, A & 22 & 119 & 1597 & 98 \\
\hline 3 & Adrian, M & 13 & 132 & 652 & 71 \\
\hline 4 & Bednar, J & 11 & 143 & 994 & 50 \\
\hline 5 & Furrer, P & 10 & 153 & 534 & 48 \\
\hline 6 & Al-Amoudi, A & 9 & 162 & 993 & 28 \\
\hline 7 & Katritch, V & 9 & 171 & 921 & 43 \\
\hline 8 & Richter, K & 6 & 177 & 461 & 23 \\
\hline 9 & Blanc, NS & 5 & 182 & 863 & 29 \\
\hline 10 & Eltsov, Mikhail & 5 & 187 & 312 & 20 \\
\hline 11 & Leforestier, A & 5 & 192 & 413 & 20 \\
\hline 12 & Studer, D & 5 & 197 & 550 & 36 \\
\hline 13 & Zuber, Benoit & 5 & 202 & 486 & 19 \\
\hline 14 & Michoud, D & 4 & 206 & 412 & 21 \\
\hline 15 & Stasiak, AZ & 4 & 210 & 337 & \\
\hline & Total of 1-15 & 210 & & 15197 & \\
\hline Total of remaining 215 & 263 & & & & \\
\hline & Grand Total & 473 & & \\
\hline NA= Number of Authorship, Cum. & Cumulative, TC= Total Citations \\
\hline
\end{tabular}

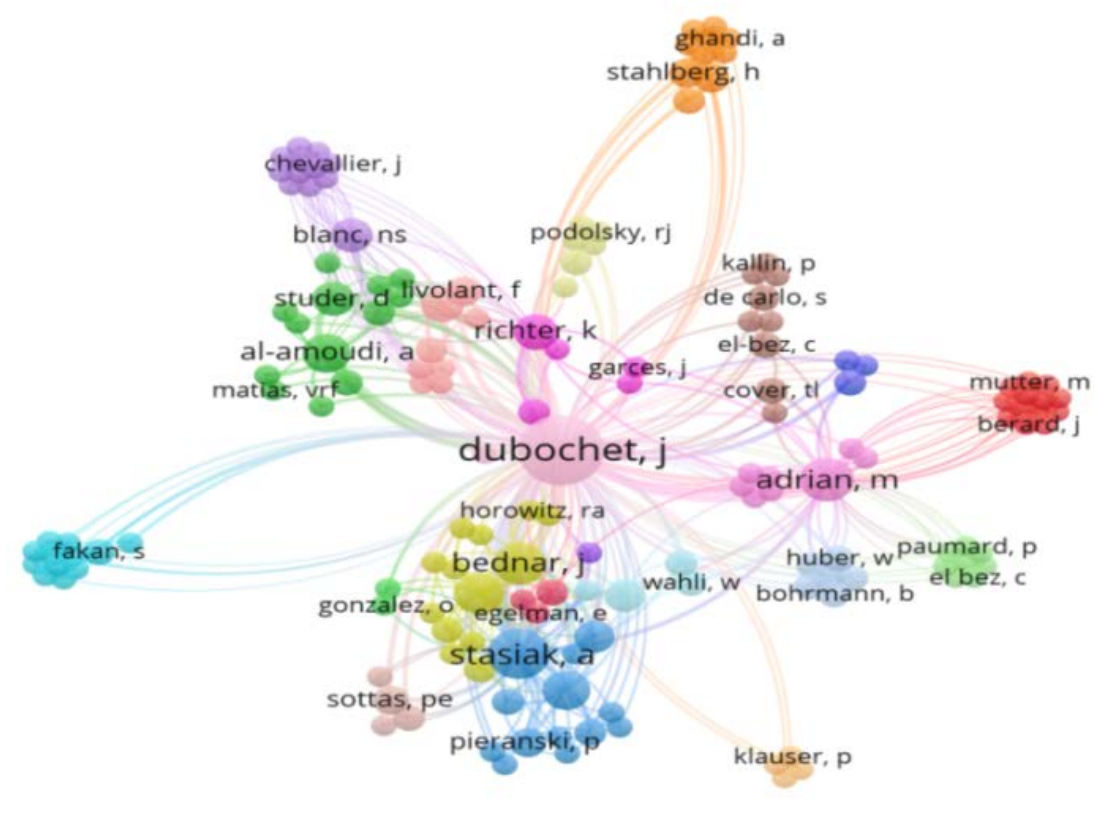

Fig. 4 Prolific Co-authors of Dubochet J 


\section{J. Highly Used Keywords in Publications of Dubochet J}

Keywords are the representation of the stuff in the papers. Table X presented the top 12 keywords (based on their occurrence) used in the publications of Dubochet; these keywords also explore the significant clue on the research theme of Dubochet. Cryoelectron Microscopyis considered the most occurred keyword, was followed by Vitrification, High-Pressure Freezing, etc.

The entire bunch of keywords that are happened in the publications of Dubochet are visualised in figure 5. These keywords may use in building thesaurus and indexing in the field.

TABLE X HIGHLY USED KEYWORDS IN PUBLICATIONS OF DUBOCHET J

\begin{tabular}{|c|l|c|c|}
\hline Sl.No. & \multicolumn{1}{|c|}{ Name of the Keyword } & Frequency & Total link Strength \\
\hline 1 & Cryoelectron Microscopy & 13 & 15 \\
\hline 2 & Vitrification & 12 & 22 \\
\hline 3 & High-Pressure Freezing & 7 & 12 \\
\hline 4 & Cryo-Electron Microscopy & 6 & 8 \\
\hline 5 & Cemovis & 4 & 8 \\
\hline 6 & Cryo-Section & 4 & 8 \\
\hline 7 & DNA Structure & 4 & 4 \\
\hline 8 & Beam Damage & 3 & 8 \\
\hline 9 & Compression & 3 & 8 \\
\hline 10 & Crevasses & 3 & 10 \\
\hline 11 & Cryo-Ultramicrotomy & 3 & 7 \\
\hline 12 & Vitreous Water & 3 & 8 \\
\hline
\end{tabular}

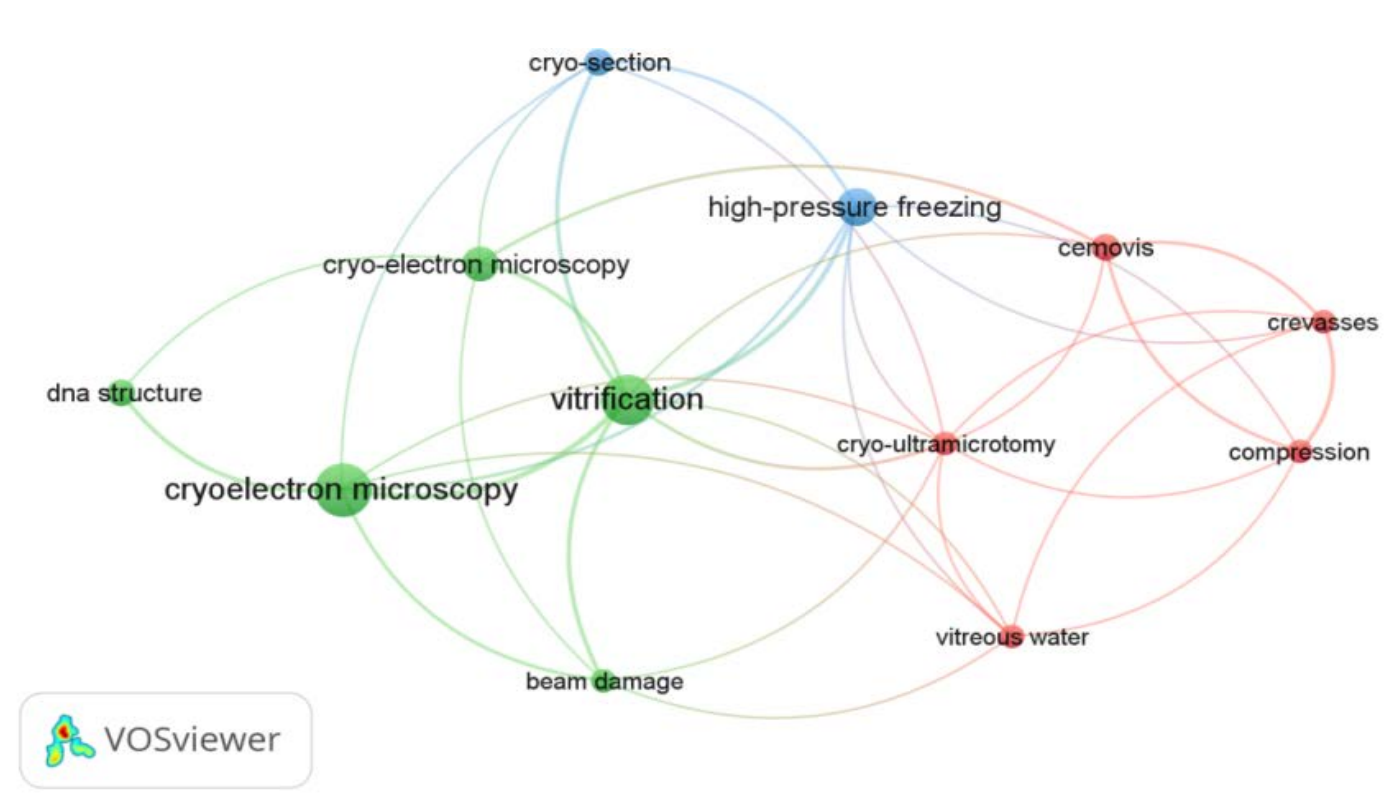

Fig.5 Clustering of keywords in publications of Dubochet $\mathrm{J}$

\section{CONCLUSION}

Studying the scientific career of an individual scientist will bring clarity to the authenticity of society's impact. The innovative world has brought remarkable changes to humankind. We can find solutions for all the problems; the scientist, the scholars, are responsible for doing something better to society and was used and esteemed by co-scientist. Dubochet and his team of authors have contributed in the way to the ordinary person's understanding of 'Cryoelectron microscopy'. This may assist for the high-resolution structure determination of biomolecules in solution. Also, the study tried to prove that she is an outstanding performer in the field of chemical sciences and a source of information for budding scientists in chemistry. The study will help budding scientists in the field and knowledge centres in selecting appropriate sources of information. 


\section{REFERENCES}

[1] Akakandelwa, A. (2008). A glimpse at a scientist: A scientometric portrait of Professors Seter Siziya. Zambia Library Association Journal, 23(1-2), 34-46.

[2] Balutagi, S., Huded, S., \& Devi, K. (2020).Measuring Research Contributions of Prof. Anurag Kumar: A Scientometric Analysis.Library Philosophy and Practice (eJournal).https://digitalcommons.unl.edu/libphilprac/4626

[3] Bibliometrix R Package. (2021). https://bibliometrix.org/index.html.

[4] Glänzel, W. (1992).On some stopping times of citation processes.From theory to indicators.Information Processing \& Management, 28(1), 53-60. https://doi.org/10.1016/03064573(92)90092-E.

[5] González-Alcaide, G. (2014). Scientometric portrait of biochemist Santiago Grisolía: Publication productivity, collaboration patterns, and citation analysis. Research Evaluation, 23(2), 150-165. https://doi.org/10.1093/reseval/rvu003

[6] Gupta, D. V. K. (1983). Chandrashekar: Winner of the 1983 Noble Prize for Physics: A Citation analysis study of his works. Annals of Library and Information and Documentation, 30(3-4), 8.

[7] Hazarika, T., Sarma, D., \& Sen, B. (2010). Scientometric portrait of Nayana Nanda Borthakur: A biometereologist. Annals of Library and Information Studies, 57(March), 12.

[8] Kademani, B. S., Kalyane, V. L., \& Kademani, A. B. (1994).Scientometric portrait of Nobel laureate Dr. C.V. Raman.Indian Journal of Information, Library and Society, 7(3-4), 215-249.

[9] Kademani, B. S., Kalyane, V. L., \& Kademani, A. B. (2002).Scientometric Portrait of Nobel Laureate Harold W. Kroto.SRELS Journal of Information Management, 39(4), 409-343.

[10] Kademani, B., Kalyane, V., \& Jange, S. (2006).Scientometric portrait of Nobel laureate Dorothy Crowfoot Hodgkin. Scientometrics, 45(2), 233-250. DOI: https://doi.org/10.1007/bf02458435.

[11] Kalyane, V. L., \& Kademani, B. S. (1997). Scientometric portrait of Barbara McClintock: The Nobel laureate in physiology. Kelpro Bulletin, 1(1), 3-14.

[12] Kalyane, V. L., \& Kalyane, S. V. (1993). Scientometric portrait of Vinodini Reddy (Journal Article (Paginated) No. 1).Journal of Information Sciences. Retrieved from http://eprints.rclis.org/4786/

[13] Kalyane, V., \& Sen, B. (1996). Scientometric portrait of Nobel laureate Pierre-Gilles de Gennes.Malaysian Journal of Library and Information Science, 1(2), 13-26.

[14] Karisiddappa, C. R., Maheshwarappa, B. S., \& Shirol, M. V. (1990). Authorship pattern and collaborative research in psychology. IASLIC Bulletin, 35(2), 73-78.

[15] Koganurmath, M. M., Angadi, M., \& Kademani, B. S. (2004). (PDF) Physics Nobel laureate Wolfgang Ketterle: A Scientometric Portrait.Malaysian Journal of Library \& Information Science, 9(2), $1-25$.

[16] Kumbar, Mallinath, \& Harinarayana, N. S. (2012). Scientometric portrait of H.S. Yathirajan.National Conference on Scientometrics Organised by Tumkur University, Tumkur. September 07, 2012, 258278.
[17] Kumbar, Prakash, \& Kumbar, Mallinath. (2021). Research Contributions of Nobel Laureate Francis H Arnold: A Study of Bibliometric Analysis. Library Philosophy and Practice (e-journal). 4996. Retrieved from https://digitalcommons.unl.edu/libphil prac/4996/

[18] Lancaster, F. W., Zeter, M. J., \& Metzler, L. (1992). Ranganathan's Influence Examined Bibliometrically. Libri, 42(3). DOI: https://doi.org/10.1515/libr.1992.42.3.268

[19] Mamdapur, G. M. N., Rajgoli, I. U., \& Mamdapur, A. K. G. (2013) Scientometric Analysis of Contributions to the Journal College and Research Libraries (1997-2011). Library Philosophy and Practice (eJournal), 16.

[20] Mamdapur, G. M. N., Rajgoli, I. U., Chavan, S. M., \& Khamitkar, K. S. (2014). Bibliometric Portrait of SRELS Journal of Information Management for the Period 2004-2013. Library Philosophy and Practice (e-Journal), 19.

[21] Otmani, M. (2017).Molecular machines- tiny by significant.Nordic Life Sciences News, Accessed from https://nordiclifescience.org/ molecular-machines-tiny-significant/on 25 December, 2020.

[22] Price, D. J. de S. (Derek J. de S., \& Price, D. J. de S. (Derek J. de S. (1986). Little science, big science-and beyond. New York: Columbia University Press. http://archive.org/details/littlescience big00pric.

[23] Qayyum, M., \& Naseer, M. M. (2013).Bio-bibliometric Study of Dr Khalid Mahmood's Contributions to LIS Field in Pakistan.Library Philosophy and Practice (e-Journal), 27.

[24] Rogers, Kara. (2019). Jacques Dubochet, Encyclopaedia Britannica, Encyclopaedia Britannica, inc. Retrieved 3 March 2020, from https://www.britannica.com /biography/Jacques-Dubochet.

[25] Rushton, J. P. (2001). A scientometric appreciation of H. J. Eysenck's contributions to psychology. Personality and Individual Differences, 31(1), 17-39. DOI: https://doi.org/10.1016/S0191-8869(00)00235-X.

[26] Sangam, S. L., Savanur, K. P., \& Sarathi, P. (2006). Communication and collaborative research pattern of professor Ramachandran: A scientometric portrait. Journal of Information Management and Scientometrics (Incorporating the COLLNET Journal), 3(1), 9-15.

[27] Sangam, S. L., Savanur, K., Manjunath, M., \& Vasudevan, R. (2006).Scientometric portrait of Prof. Peter John Wyllie.Scientometrics, 66(1), 43-53. DOI: https://doi.org/10.1007/s 11192-006-0004-5.

[28] Shri Ram \& Faizul, N. (2020).Highly cited articles in Coronavirus research: A Bibliometric analysis.DESIDOC Library and Information Technology, 40(4), 218-229. DOI: https://doi.org/10.14429/djlit. 40.4.15671.

[29] Soni, Navin Kumar et al., (2020). Evaluation of usage of E-resources and INMAS library services through user's perspective: An analysis study. DESIDOC Library and Information Technology, 40(4), 238246. DOI: https://doi.org/10.14429/djlit.40.4.16047.

[30] Varaprasad, S. J. D., Sahoo, S., \& S, M. (2010). Research Contributions of J.S. Yadav to Chemical Sciences: A Scientometric Study. Malaysian Journal of Library \& Information Science, 15(2), 41-55. 